PETUNJUK MEMBUAT MAKALAH

\title{
ALAMAT MENGAJUKAN GUGATAN DAN TUNTUTAN DI PENGADILAN TATA USAHA NEGARA
}

\author{
Nama : Yufitrio Damelius Dachi \\ Email : yufitriodamelius@gmail.com \\ No.Bp : 1910003600358 \\ Perguruan Tinggi : Universitas Ekasakti Padang
}

\section{A. PENDAHULUAN}

Peradilan Tata Usaha Negara merupakan salah satu peradilan di Indonesia yang berwenang untuk menangani sengketa Tata Usaha Negara. Berdasarkan Undang-Undang Nomor 5 Tahun 1986 sebagaimana telah dirubah oleh UU No. 9/2004 tentang Peradilan Tata Usaha Negara (UU PTUN), Peradilan Tata Usaha Negara diadakan untuk menghadapi kemungkinan timbulnya perbenturan kepentingan, perselisihan, atau sengketa antara Badan atau Pejabat Tata Usaha Negara dengan warga masyarakat. UU PTUN memberikan 2 macam cara penyelesaian sengketa TUN yakni upaya administrasi yang penyelesaiannya masih dalam lingkungan administrasi pemerintahan sendiri serta melalui gugatan ke Pengadilan Tata Usaha Negara (PTUN).

Dalam PTUN, seseorang dapat mengajukan gugatan terhadap kebijakan pemerintah yang dipercaya telah merugikan individu dan atau masyarakat. Subjek atau pihak-pihak yang berperkara di Pengadilan Tata Usaha Negara ada 2 yakni, Pihak penggugat, yaitu seseorang atau Badan Hukum Perdata yang merasa kepentingannya dirugikan dengan dikeluarkannya Keputusan Tata Usaha Negara (KTUN) oleh Badan 


\section{PETUNJUK MEMBUAT MAKALAH}

atau Pejabat Tata Usaha Negara, serta Pihak Tergugat, yaitu Badan atau Pejabat Tata Usaha Negara yang mengeluarkan Keputusan berdasarkan wewenang yang ada padanya atau yang dilimpahkan kepadanya. Dalam Undang Undang Nomor 9 Tahun 2004 tentang Perubahan atas Undang-Undang Nomor 5 Tahun 1986 tentang Peradilan Tata Usaha Negara (Perubahan UU PTUN), pihak ketiga tidak dapat lagi melakukan intervensi dan masuk ke dalam suatu sengketa TUN.

Kekuasaan kehakiman dilingkungan Peradilan Tata Usaha Negara dalam UU PTUN dilaksanakan oleh Pengadilan Tata Usaha Negara dan Pengadilan Tinggi Tata Usaha Negara yang berpuncak pada Mahkamah Agung. Pengadilan Tinggi Tata Usaha Negara pada dasamya merupakan pengadilan tingkat banding terhadap sengketa yang telah diputus oleh Pengadilan Tata Usaha Negara, kecuali dalam sengketa kewenangan mengadili antar Pengadilan Tata Usaha Negara di daerah hukumnya serta sengketa yang terhadapnya telah digunakan upaya administratif. Adapun hukum acara yang digunakan pada Peradilan Tata Usaha Negara mempunyai persamaan dengan hukum acara yang

digunakan pada Peradilan Umum untuk perkara Perdata, dengan perbedaan dimana Peradilan Tata Usaha Negara Hakim berperan lebih aktif dalam proses persidangan guna memperoleh kebenaran materiil dan tidak seperti dalam kasus gugatan perdata, gugatan TUN bukan berarti menunda dilaksanakannya suatu KTUN yang disengketakan. 


\section{B. PEMBAHASAN}

\section{PENGAdILAN TATA USAHA NEGARA (PTUN)}

Pengadilan Tata Usaha Negara (PTUN) dibentuk dengan Keputusan Presiden (Keppres), dan sampai dengan sekarang ada 26 PTUN. Berdasarkan Keppres No. 52 Tahun 1990 tentang Pembentukan PTUN di Jakarta, Medan, Palembang, Surabaya, Ujung Pandang. Keppres No. 16 Tahun 1992 tentang Pembentukan PTUN di Bandung, Semarang dan Padang. Keppres No. 41 Tahun 1992 tentang Pembentukan PTUN Pontianak, Banjarmasin dan Manado. Keppres No. 16 Tahun 1993 tentang Pembentukan PTUN Kupang, Ambon, dan Jayapura. Keppres No. 22 Tahun 1994 tentang Pembentukan PTUN Bandar Lampung, Samarinda dan Denpasar. Keppres No. 2 Tahun 1997tentang Pembentukan PTUN Banda Aceh, Pakanbaru, Jambi, Bengkulu, Palangkaraya, Palu, Kendari, Yogyakarta, Mataram dan Dili. Untuk wilayah hukum PTUN Dili, setelah Timor Timur merdeka bukan lagi termasuk wilayah Republik Indonesia.PTUN mempunyai wewenang untuk memeriksa, memutus dan menyelesaikan sengketa tata usaha negara pada tingkat pertama.

\section{PROSES MENGAJUKAN GUGATAN DAN TUNTUTAN BIAYA} BERPERKARA DI PENGADILAN TATA USAHA NEGARA (PTUN)

Berikut ini adalah Tahapan-Tahapan Prosedur Pengajuan Gugatan dan Biaya Berperkara Di Pengadilan Tata Usaha Negara Jakarta sebagai berikut :

a) Pihak Berperkara (Penggugat) Datang Ke Pengadilan Tata Usaha Negara Jakarta (PTUN Jakarta) Dengan Membawa :

- Surat Gugatan Rangkap 8 (Delapan) Disertai Soft Copy Gugatannya. 
PETUNJUK MEMBUAT MAKALAH

- Foto Copy Objek Sengketa Sejumlah 1 (Satu) Eksemplar (Apabila Sudah Ada).

- Foto Copy Kartu Tanda Penduduk (KTP) Para Pihak Sejumlah 1 (Satu) Eksemplar.

- Surat Kuasa Sejumlah 8 (Delapan) Eksemplar Disertai Foto Copy Kartu Pengenal Advokat (Apabila Dikuasakan).

b) Petugas Meja Pertama Menerima Gugatan / Permohonan Beserta Kelengkapannya.

c) Petugas Meja Pertama Memeriksa Kelengkapan Berkas Dengan Menggunakan Daftar Periksa (Check List) dan Meneruskan Berkas yang Telah Selesai Diperiksa Kelengkapannya Kepada Panitera Muda Perkara Untuk Menyatakan Berkas Telah Lengkap atau Tidak Lengkap.

d) Panitera Muda Perkara Meneliti Berkas :

- Apabila Berkas Belum Lengkap : Panitera Muda Perkara Mengembalikan Berkas Dengan Melampirkan Daftar Periksa Supaya Penggugat Dapat Melengkapi Kekurangannya.

- Apabila Berkas Sudah Lengkap : Dikembalikan Kepada Petugas Meja Pertama.

e) Pihak Penggugat Membayar Panjar Biaya Perkara Sebesar Rp. 650.000,- (Enam Ratus Lima Puluh Ribu Rupiah) Melalui Bank BRI Atau Via Transfer ATM Bank BRI Dengan Nama : 
PETUNJUK MEMBUAT MAKALAH

\section{Biaya Perkara PTUN Jakarta \\ Rekening BRI Cabang Jatinegara}

No. Rekening : $0122-01-000912-30-2$

- Keputusan Ketua Pengadilan Tata Usaha Negara Jakarta Nomor : W2.TUN1/1020B/HK.06/IV/2019 tentang Panjar Biaya Perkara dan Pengelolaannya pada Pengadilan Tata Usaha Negara Jakarta. SK Ketua Tentang Biaya Perkara dan Pengelolaannya.

- Surat Edaran Mahkamah Agung RI Nomor 04 Tahun 2008 Tentang Pemungutan Biaya Perkara.

f) Pihak Penggugat Setelah Membayar Panjar Biaya Perkara, Menyerahkan Slip Bukti Penyetoran Kepada Kasir / Meja Pertama.

g) Petugas Meja Pertama Membuat Surat Kuasa Untuk Membayar (SKUM) Sebesar Rp. 500.000,- (Lima Ratus Ribu Rupiah) dan Kasir / Meja Pertama Mencatat Dalam Buku Jurnal.

h) Petugas Meja Kedua Mencatat Gugatan Dalam Buku Register Induk Perkara. Petugas Meja Pertama Memproses Gugatan.

i) Petugas Meja Kedua Memasukan Nomor Perkara, Identitas Para Pihak, Obyek Sengketa, Posita dan Petitum Gugatan Dalam Aplikasi Sistem Informasi Administrasi Tata Usaha Negara Jakarta (SIAD TUN Jakarta). 


\section{PETUNJUK MEMBUAT MAKALAH}

j) Petugas Meja Pertama Menyerahkan SKUM dan Salinan Gugatan yang Telah Didaftar Serta Telah Ditandatangani Oleh Panitera Kepada Pihak Penggugat. PENDAFTARAN SELESAI

Selanjutnya Pihak-Pihak Berperkara akan Dipanggil Melalui Surat Tercatat Menghadap Ke Pengadilan Untuk : Dismissal Proses / Pemeriksaan Persiapan / Persidangan.

\section{PENUTUP}

1. Peradilan Tata Usaha Negara merupakan salah satu peradilan di Indonesia yang berwenang untuk menangani sengketa Tata Usaha Negara. Berdasarkan UndangUndang Nomor 5 Tahun 1986 sebagaimana telah dirubah oleh UU No. 9/2004 tentang Peradilan Tata Usaha Negara (UU PTUN).

2. Pengadilan Tata Usaha Negara (PTUN) dibentuk dengan Keputusan Presiden (Keppres), dan sampai dengan sekarang ada 26 PTUN.

3. Implikasi Putusan Pengadilan Tata Usaha Negara dengan diterbitkannya Surat Keputusan Tata Usaha Negara yang isinya memberhentikan penggugat. penggugat sudah tidak tidak bekerja lagi di Dinas Kepolisian Negara Republik Indonesia karena putusan tersebut telah berkekuatan hukum tetap. 


\section{PETUNJUK MEMBUAT MAKALAH}

\section{DAFTAR PUSTAKA}

Darmini Roza dan Laurensius Arliman S Peran Pemerintah Daerah Di Dalam Melindungi Hak Anak Di Indonesia, Masalah-Masalah Hukum, Volume 47, Nomor 1, 2018.

Laurensius Arliman S, Komnas HAM dan Perlindungan Anak Pelaku Tindak Pidana, Deepublish, Yogyakarta, 2015. 


\section{PETUNJUK MEMBUAT MAKALAH}

Laurensius Arliman S, Penguatan Perlindungan Anak Dari Tindakan Human Trafficking Di Daerah Perbatasan Indonesia, Jurnal Selat, Volume 4, Nomor 1, 2016.

Laurensius Arliman S, Problematika Dan Solusi Pemenuhan Perlindungan Hak Anak Sebagai Tersangka Tindak Pidana Di Satlantas Polresta Pariaman, Justicia Islamica, Volume 13, Nomor 2, 2016.

Laurensius Arliman S, Pelaksanaan Perlindungan Anak Yang Tereksploitasi Secara Ekonomi Oleh Pemerintah Kota Padang, Veritas et Justitia, Volume 2, Nomor 1, 2016.

Laurensius Arliman S, Kedudukan Ketetapan MPR Dalam Hierarki Peraturan PerundangUndangan Di Indonesia, Lex Jurnalica, Volume 13, Nomor 3, 2016.

Laurensius Arliman S, Komnas Perempuan Sebagai State Auxialiary Bodies Dalam Penegakan Ham Perempuan Indonesia, Justicia Islamica, Volume 14, Nomor 2, 2017.

Laurensius Arliman S, Peranan Pers Untuk Mewujudkan Perlindungan Anak Berkelanjutan Di Indonesia, Jurnal Ilmu Hukum Tambun Bungai, Volume 2, Nomor 2, 2017.

Laurensius Arliman S, Mewujudkan Penegakan Hukum Yang Baik Untuk Mewujudkan Indonesia Sebagai Negara Hukum, Jurnal Hukum Doctrinal, Volume 2, Nomor 2, 2017.

Laurensius Arliman S, Participation Non-Governmental Organization In Protecting Child Rights In The Area Of Social Conflict, The 1st Ushuluddin and Islamic Thought International Conference (Usicon), Volume 1, 2017.

Laurensius Arliman S, Partisipasi Masyarakat Dalam Pembentukan Perundang-Undangan Untuk Mewujudkan Negara Kesejahteraan Indonesia, Jurnal Politik Pemerintahan Dharma Praja, Volume 10, Nomor 1, 2017, https://doi.org/10.33701/jppdp.v10i1.379. 


\section{PETUNJUK MEMBUAT MAKALAH}

Laurensius Arliman S, Peran Komisi Perlindungan Anak Indonesia Untuk Mewujudkan Perlindungan Anak, Jurnal Respublica Volume 17, Nomor 2, 2018.

Laurensius Arliman S, Menjerat Pelaku Penyuruh Pengrusakan Barang Milik Orang Lain Dengan Mempertimbangkan Asas Fungsi Sosial, Jurnal Gagasan Hukum, Volume 1, Nomor 1, 2019.

Laurensius Arliman S, Ilmu Perundang-Undangan Yang Baik Untuk Negara Indonesia, Deepublish, Yogyakarta, 2019.

Laurensius Arliman S, Isdal Veri, Gustiwarni, Elfitrayenti, Ade Sakurawati, Yasri, Pengaruh Karakteristik Individu, Perlindungan Hak Perempuan Terhadap Kualitas Pelayanan Komnas Perempuan Dengan Kompetensi Sumber Daya Manusia Sebagai Variabel Mediasi, Jurnal Menara Ekonomi: Penelitian dan Kajian Ilmiah Bidang Ekonomi, Volume 6, Nomor 2, 2020.

Laurensius Arliman S, Pendidikan Kewarganegaraan, Deepublish, Yogyakarta, 2020.

Laurensius Arliman S, Makna Keuangan Negara Dalam Pasal Pasal 23 E Undang-Undang Dasar 1945, Jurnal Lex Librum, Volume 6, Nomor 2 Juni 2020, http://dx.doi.org/10.46839/1ljih.v6i2.151.

Laurensius Arliman S, Kedudukan Lembaga Negara Independen Di Indonesia Untuk Mencapai Tujuan Negara Hukum, Kertha Semaya Journal Ilmu Hukum, Volume 8, Nomor 7, 2020.

Laurensius Arliman S, Pelaksanaan Assesment Oleh Polres Kepulauan Mentawai Sebagai Bentuk Pelaksanaan Rehabilitasi Bagi Pecandu Dan Korban Penyalahgunaan Narkotika, Jurnal Muhakkamah, Volume 5, Nomor 1, 2020. 


\section{PETUNJUK MEMBUAT MAKALAH}

Laurensius Arliman S, Aswandi Aswandi, Firgi Nurdiansyah, Laxmy Defilah, Nova Sari Yudistia, Ni Putu Eka, Viona Putri, Zakia Zakia, Ernita Arief, Prinsip, Mekanisme Dan Bentuk Pelayanan Informasi Kepada Publik Oleh Direktorat Jenderal Pajak, Volume 17, No Nomor, 2020.

Larensius Arliman S, Koordinasi PT. Pegadaian (Persero) Dengan Direktorat Reserse Narkoba Polda Sumbar Dalam Penimbangan Barang Bukti Penyalahgunaan Narkotika, UIR Law Review, Volume 4, Nomor 2, 2020, https://doi.org/10.25299/uirlrev.2020.vol4(1).3779.

Laurensius Arliman S, Tantangan Pendidikan Kewarganegaraan Pada Revolusi 4.0, Ensiklopedia Sosial Review, Volume 2, Nomor 3, 2020.

Muhammad Afif dan Laurensius Arliman S, Protection Of Children's Rights Of The Islamic And Constitutional Law Perspective Of The Republic Of Indonesia, Proceeding: Internasional Conference On Humanity, Law And Sharia (Ichlash), Volume 1, Nomor 2, 2020.

Otong Rosadi danLaurensius Arliman S, Urgensi Pengaturan Badan Pembinaan Idelogi Pancasila Berdasarkan Undang-Undang Sebagai State Auxiliary Bodies yang Merawat Pancasila dalam Perspektif Hak Asasi Manusia, Prosiding Konferensi Nasional Hak Asasi Manusia, Kebudayaan dan Tujuan Pembangunan Berkelanjutan Indonesia pada Masa Pandemi Covid-19: Tantangan untuk Keilmuan Hukum dan Sosial Volume 1, Universitas Pancasila, Jakarta, 2020. 